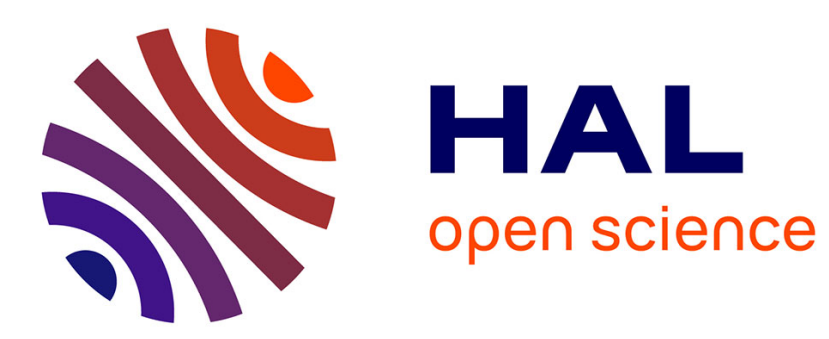

\title{
Credit Rationing in Rural Credit Markets of India
}

Kausik Chaudhuri, Mary Cherical

\section{To cite this version:}

Kausik Chaudhuri, Mary Cherical. Credit Rationing in Rural Credit Markets of India. Applied Economics, 2011, pp.1. 10.1080/00036846.2010.524627 . hal-00675394

\section{HAL Id: hal-00675394 https://hal.science/hal-00675394}

Submitted on 1 Mar 2012

HAL is a multi-disciplinary open access archive for the deposit and dissemination of scientific research documents, whether they are published or not. The documents may come from teaching and research institutions in France or abroad, or from public or private research centers.
L'archive ouverte pluridisciplinaire HAL, est destinée au dépôt et à la diffusion de documents scientifiques de niveau recherche, publiés ou non, émanant des établissements d'enseignement et de recherche français ou étrangers, des laboratoires publics ou privés. 


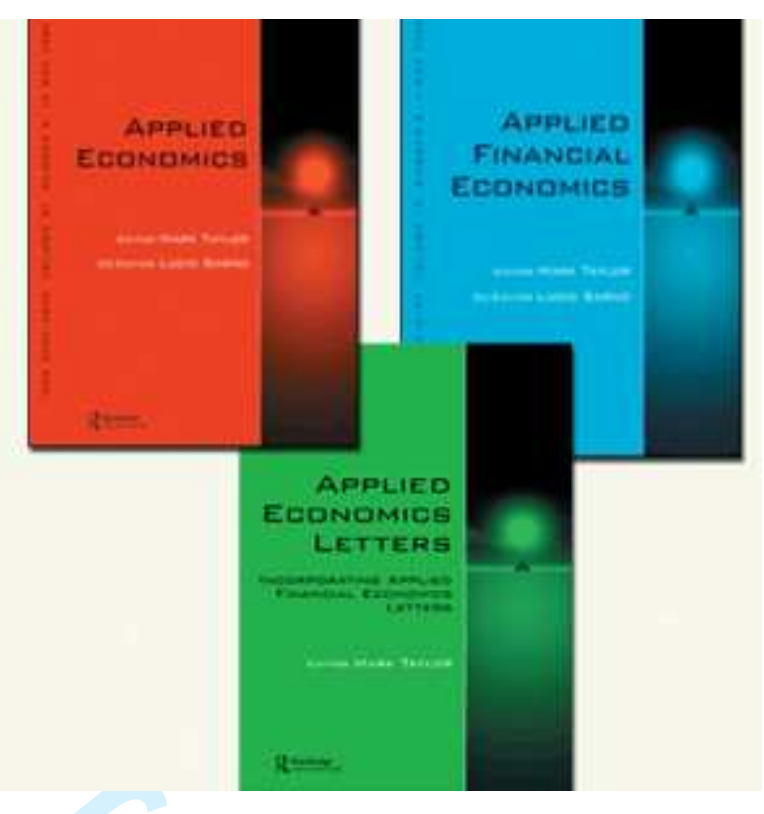

\section{Credit Rationing in Rural Credit Markets of India}

\begin{tabular}{|c|c|}
\hline Journal: & Applied Economics \\
\hline Manuscript ID: & APE-07-0706.R1 \\
\hline Journal Selection: & Applied Economics \\
\hline $\begin{array}{r}\text { Date Submitted by the } \\
\text { Author: }\end{array}$ & 29-Jan-2009 \\
\hline Complete List of Authors: & $\begin{array}{l}\text { Chaudhuri, Kausik; Leeds University Business School } \\
\text { Cherical, Mary; IGIDR }\end{array}$ \\
\hline JEL Code: & $\begin{array}{l}\text { O20 - General < O2 - Development Planning and Policy < O - } \\
\text { Economic Development, Technological Change, and Growth, O12 - } \\
\text { Microeconomic Analyses of Economic Development < O1 - } \\
\text { Economic Development < O - Economic Development, } \\
\text { Technological Change, and Growth, O53 - Asia including Middle East } \\
<\text { O5 - Economywide Country Studies < O - Economic } \\
\text { Development, Technological Change, and Growth }\end{array}$ \\
\hline Keywords: & Credit rationing, Formal sector, India \\
\hline
\end{tabular}

\section{(s) ScholaroNE" \\ Manuscript Central}




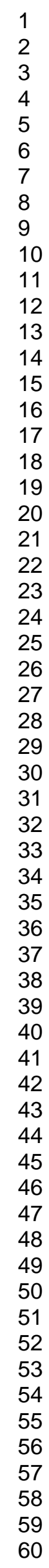

14

15

16

18

19

20

22

23

25

26

27

29

30

32

33

34

35

36

37

39

40

41

42

44

45

46

47

48

49

51

52

54

55

57

58

59

60

Editorial Office, Dept of Economics, Warwick University, Coventry CV4 7AL, UK 


\title{
Credit Rationing in Rural Credit Markets of India
}

\author{
Kausik Chaudhuri* \\ Department of Economics \\ Leeds University Business School \\ Leeds LS2 9JT, United Kingdom \\ and \\ Madras School of Economics \\ Gandhi Mandapam Road, Chennai 600 025, India \\ and \\ Mary M. Cherical \\ Indira Gandhi Institute of Development Research \\ Gen. Vaidya Marg, Goregaon (East) \\ Mumbai 400 065, India
}

\begin{abstract}
This paper analyses the prevalent situation of the formal financial institutions in rural India using data from National Sample Survey $54^{\text {th }}$ Round (January-June, 1998). We use sample selectivity model to examine the sanction of the loan by the financial institutions as a two-stage process. We model the choice of the household's credit requirement using an unordered choice model, namely, a multinomial logit model. Our results reveal that the rural households are considerably credit constrained. The households who do not have an account in a financial institution have a lower chance of obtaining the loan and households who are credit constrained have relatively lower land holding and they do not possess livestock. Households who borrow for non-farm purpose exhibit a lower chance of obtaining credit compared to those households who borrow for farm business. Village level infrastructure plays an important role in determining the credit rationing behaviour in rural-India.

Key Words: Credit rationing, Formal Sector, India JEL Classification: O12, O20, O53.

* Corresponding author, email: kc@lubs.leeds.ac.uk. We would like to thank an anonymous referee and the Editor for their comments. Usual disclaimer applies.
\end{abstract}




\section{Credit Rationing in Rural Credit Markets of India}

\section{Introduction}

Government intervention is a common phenomenon in the rural credit markets of developing countries. India was no different in this aspect. The intervention in India took the form of nationalisation of banks, bank branch expansion and the subsidisation of credit to the priority sector. The rural credit markets in developing countries are dual in nature, with the existence of the formal and informal credit markets. The informal sector, in general, charges exorbitant rates of interest on loans whilst the collateral requirement is negligible. The agricultural sector's need for cheap and timely credit necessitated government intervention, which intended to counter the predominance of the informal sector. Furthermore, the informal credit sector acted as a deterrent to the growth of the rural sector. Hence, the government emphasised on spreading banking facilities in the rural areas.

Existing research supports government intervention based on adverse selection, moral hazard, and contract enforcement problems that would affect the level of investment (Stiglitz et al., 1981). In addition, credit rationing in rural credit markets may be present due to increased market power in the hands of a few, who have access to information (Besley, 1994). However, the interventionist policy of the government has led to the misallocation of resources. This was because the interest rates were kept artificially lower than the market rates, allocation of credit went into the hands of the powerful, and political precedence took over economic ones. The issue of credit rationing in the formal credit markets arises, as the rural poor are not able to furnish collateral as a guarantee for a loan. Based on their asset holdings, households are found to be credit rationed. Bhende (1986) using data from three ICRISAT villages demonstrates this type of credit rationing based on attributes like higher education, older head of households, larger family size, and larger farm size. 
Evidence also exists towards credit constrained situation of rural households by the formal financial institutions (Zeller (1994), Kochar (1997), Diagne (1999), Duong and Izumida (2002), Pal (2002), Swain (2002)). Diagne (1999) discusses the determinants of household access and participation in both the formal and informal credit markets of Malawi using the concept of credit limit. The paper expounds the importance of composition of assets rather than its monetary value or land holding and reveals that formal and informal sectors are imperfect substitutes and households are credit constrained in both the sectors. The study further elucidates that households give more importance to easy access to credit rather than the actual costs involved in getting credit. This calls for the removal of the subsidised rates of interest prevailing in the markets. In this context, we note that in India, interest rates were deregulated in 1994. Before 1994, India followed the administered interest rate mechanism. ${ }^{1}$

The importance of access to credit can arise due to various factors: firstly, in case of large seasonal fluctuations in income, it can smooth consumption requirements. Secondly, credit can be used as a source of finance for both working and investment capital for the households who do not have much savings. Finally, an emergency event such as illness can create the pressure to borrow.

In the informal sector, monitoring may fail if the distribution of returns from investments is influenced by the actions of the borrowers. Highly indebted individual may not have the incentive to work hard as a significant proportion of the return would be utilised for repayment purpose. In this case, high interest rates create a debt-overhang problem and the informal lenders may not raise the interest rate beyond a critical level. Besides, with limited funds, not all applicants may get credit.

\footnotetext{
${ }^{1}$ On administered interest rate regime, see http://rbidocs.rbi.org.in/rdocs/PublicationReport/docs/59598.doc.
} 
Against the backdrop of the rural credit market, this paper tries to examine the following two questions. We first deal with the joint determination of households' requirement for credit and the financial institutions decision on granting the loan. This way of modelling takes care of the sample selection bias that was inherent if we just include only those households who have applied for a loan. The second pertains to the choice of the household whether to apply for a loan and if so, then from which financial institution/s. We address these questions using data from the $54^{\text {th }}$ round of the National Sample Survey (NSS) on Consumer Expenditure and Common Property Resources conducted in January - July 1998.

The results indicate that credit rationing does exit in the formal credit market in ruralIndia. The households with an account in a financial institution have a higher probability of applying and receiving a loan compared to no-account households. The households who possess lower land holding are significantly credit constrained than those who possess large land holding. Female headed household although has a lower chance of applying for a loan but the probability of receiving loan given that they have applied, are higher than their male counterpart. Livestock possession is considered as collateral that is liquid in nature. Hence, those households who own livestock have a greater chance of receiving a loan. The indices, which measure the wealth of the household, reveal that households who have a higher durable goods index have a greater chance of participating in the credit market. The presence of a financial institution in the village as well as adequate infrastructure facility increases the probability of the households demand and the supply of loans by financial institutions.

The paper is organised in the following manner. Section 2 discuses the data and the variable used in the analysis. The empirical model along with the obtained results is presented in Section 3. Section 4 presents the results and Section 5 contains the conclusion. 


\section{Data and Variable Construction}

The data for our analysis has been extracted from the Consumer Expenditure and Common Property Resources, National Sample Survey $54^{\text {th }}$ Round (January-June, 1998$) .{ }^{2}$ We have used the rural household data for the fifteen major states of India. Our sample indicates that $88.52 \%$ of the households did not apply for a loan from any of the financial institutions in the past two years before the date of survey whereas $10.35 \%$ of the households in the sample applied to at least one financial institution. ${ }^{3}$ The number of households who applied to more than one financial institution accounted for less than $1.2 \%$ of the sample surveyed. Out of the total 7,415 households applied for loan, $20.11 \%$ of households were not granted the loan.

Our aim is to explain the credit rationing in terms of household and village level characteristics. The first set of household variable are the family size, sex of the household head, and age of the household head. The size of the family is a major determinant of borrowing by households as larger the size of the family; the greater would be their credit requirements. The average size of the family is around five in our sample. Past studies have dwelt upon the importance of women and credit and in general document the better repayment behaviour by women. Thus, the sex of the household head (dummy taking the value of one if the household head is female) is used to check for any gender specific impact. Around nine percent of the head of the households are women in the sample. To perceive the link between the age of the household head and the credit requirement the age of the household head is included. ${ }^{4}$ We include the social group dummies to capture whether the households are discriminated in the

\footnotetext{
2 For a detail on the survey methodology, see NSS Reports No. 449-452, http://mospi.nic.in/mospi_nsso_rept_pubn.htm.

${ }_{3}^{3}$ Note, the individual can apply for a loan either to a bank, or to credit cooperative society (CCS) or a to a self-help group (SHG).

${ }^{4}$ See Bhende (1986) on this.
} 
credit market based on their social groups and the same is the case with occupational dummies. ${ }^{5}$ In our sample, $13 \%$ of the households belong to scheduled tribe, $21 \%$ to scheduled caste and $27 \%$ to other backward caste. In absence of information on educational status, we use subscription of newspaper dummy as a proxy to capture the literacy as well as awareness of the household. Most of the sampled households are engaged in agricultural activities as their major occupation (about $56 \%)$

The second set of household variables captures the economic condition. We include possession of livestock (dummy taking the value of one in case of possession), land holding dummies, durable good index, and household living condition index. The two indices, namely durable good index, and household living condition index are used as proxies for wealth of the household. ${ }^{6}$ This would enable us to capture the separate effect of durable goods in addition to household living condition in obtaining a loan. The asset index of durable goods comprise of the variables that capture possession of the following gadgets - Television, Telephone, Radio, Electric Pump, and Diesel Pump. The index used to capture the household's living condition includes the following variables: source of drinking water, bathroom type, drainage arrangement for wastewater, and latrine type. ${ }^{7}$ Livestock possession (dummy) is included as it is often used as collateral, which is liquid in nature. Hence, possession of livestock improves the chances of the household in obtaining credit. Land possession (dummies) would be indicative whether the household is in a position to furnish collateral for a loan. Following the definition of the Reserve Bank of India, we divide the land holding into three categories: small ( $>0-2.5$ acres), medium

\footnotetext{
${ }^{5}$ The policy of the financial institutions, in particular, the scheduled commercial banks is to lend a certain amount to the priority sector, of which, $18 \%$ is allotted to agricultural credit. The occupation type dummies would hence, indicate if the agricultural households were favoured over the other households in terms of occupational status.

${ }^{6}$ The data on consumer expenditure cannot be used in our study due to the mismatch in the number of household surveyed in the main and special subjects' surveys. Constrained by this problem, we use the data on household assets to measure wealth of a household (Filmer et al. (2001)). In order to do so, we create the durable goods index and living condition index from a set of asset indicators using principal component analysis.

${ }^{7}$ The mean value of the index is zero by construction.
} 
(2.51-5 acres) and large (above 5 acres) dummies. Moreover, the land holding dummies would divulge whether credit rationing exists based on the size of the land holding. In our sample about $56 \%$ of the households can be termed as small farmers.

Finally, we have used information on whether the household has an account in a financial institution or belonging to a CCS/SHG as well as on the purpose of loan. Having an account should increase the probability of a household to borrow from a financial institution where as the purpose for loan dummy would indicate whether a certain purpose of loan was given greater importance over others. About $30 \%$ of the households in our sample have an account in a financial institution.

The village level facilities are captured by the financial institutions dummies (Banks, $\mathrm{RRB}, \mathrm{CCS}$, and SHG) indicating the presence of the financial institution in the village. The infrastructure index is used to control for the level of infrastructure in the village. The educational index is used to control for the presence of educational institutions in the village. ${ }^{8}$

\section{Empirical Methodology}

The sanction of the loan by the financial institutions is a two-stage process. Sanction can be given for only those households who have applied for a loan from a financial institution. Given this, we estimate a model with sample selection following Heckman (1979) with respect to loan applicants to (1) banks and (2) CCS after having controlled for village level facilities. Consider the following:

$Y_{1 i}=X_{1 i} \beta_{1}+u_{1 i}$

$Y_{2 i}=X_{2 i} \beta_{2}+u_{2 i}$

\footnotetext{
${ }^{8}$ We have followed the same procedure as in case of household asset index to construct the facility indices at the village level. For construction of infrastructure facility index, we use presence of railway station, bus stop, Metalled road, post office, telegraph office and telephone booth. The presence of primary, secondary and tertiary schools is used to construct the educational index.
} 
where ' $i$ ' $=(1, \ldots ., \mathrm{n}), X_{j i}$ is a $1 \times K_{j}$ vector of covariates, $\beta_{\mathrm{j}}$ is a $\mathrm{K}_{\mathrm{j}} \mathrm{X} 1$ vector of parameters. The data is observable on $Y_{1 i}$ if $Y_{2 i}>0$ i.e. if the household has applied for a loan, while there is no observation if $Y_{2 i} \leq 0$ i.e. if household did not apply for a loan.

Our next model examines the choice behaviour of the household in deciding whether to apply for a loan and if they do, then from which financial institution they would seek the loan. Hence, the household, in other words, compares the utility arising from applying for a loan from a specific financial institution/s and not applying for a loan at all. This model primarily models the choice of the household's credit requirement and is an unordered choice model, namely using a multinomial logit model $(M N L){ }^{9}$

Given our data, there are eight choices from which the household decides its preference apply for a loan from a bank, apply for a loan from CCS, apply for a loan from SHG, apply to Bank and CCS, apply to CCS and SHG, apply to SHG and Bank, apply to all and not apply for a loan. Let $P_{1}, P_{2}, P_{3}, P_{4}, P_{5}, P_{6}, P_{7}$, and $P_{8}$ be the probabilities associated with these eight choices. In this case, we take 'not apply for a loan' as the base category. Hence,

$$
\frac{P_{j}}{P_{m}}=\frac{F\left(X \beta_{j}\right)}{1-F\left(X \beta_{j}\right)}=\exp \left(X \beta_{j}\right) \quad(j=1,2, \ldots \ldots ., m-1) \text { where } m=8
$$

Since,

$$
\sum_{j=1}^{m-1} \frac{P_{j}}{P_{m}}=\frac{1-P_{m}}{P_{m}}=\frac{1}{P_{m}}-1
$$

We have

$$
P_{m}=\left[\frac{1}{1+\sum_{j=1}^{m-1} \exp \left(X \beta_{j}\right)}\right]
$$

and

\footnotetext{
${ }^{9}$ One can use nested logit or conditional logit here. We test for the Independence of Irrelevant Alternatives (IIA) assumption using both Hausman and Small-Hsiao test. Our results indicate that IIA assumption holds for the model.
} 


$$
P_{j}=\left[\frac{\exp \left(X \beta_{j}\right)}{1+\sum_{j=1}^{m-1} \exp \left(X \beta_{j}\right)}\right]
$$

The Likelihood function is given as

$$
L=\prod_{i=1}^{n} P_{i 1}^{Y i 1} P_{i 2}^{Y i 2} \ldots P_{i m}^{Y i m}
$$

In addition, the log likelihood is

$$
\log L=\sum_{i=1}^{n} \sum_{j=1}^{m} y_{i j} \log P_{i j}
$$

In the multinomial logit regression model, the relative risk ratio is reported as it facilitates easy comparison across categories.

\section{Regression Results}

We report our regression results separately in terms of household variables and village characteristics first for the sample selection model and then for the multinomial model.

\section{Sample Selection Model}

$\underline{\text { Household Characteristics }}$

The results for the sample selection model are reported in Table 1 and Table 2. The results indicate that larger the family, higher is the probability of applying for a loan from both institutions. In the main equation (after correcting for sample selection), the coefficient of family size is negative indicating that larger the family the probability of receiving a loan is lower in the case of loans from Banks. ${ }^{10}$ Female-headed household shows less chance of applying for a loan, however, the probability of loan approval is higher for them. The coefficient of the age of the household head is positive and insignificant. The occupation type of the household has a negative and significant impact on loan approval from banks. The chances of receiving a loan from a bank improve if the household head is a woman. The probability of loan application to both agencies

\footnotetext{
${ }^{10}$ The effect is not significant in case of loan approved by CCS.
} 
increases if the household has an account in a financial institution. However, note except the sex, family size or the age of the head of household, the other variables are not significant in loan approval equation.

Does the economic condition matter? Our results document that it matters in case of loan application but not for loan approval. The coefficient of land possession dummy reveals interesting pattern. The coefficient is larger as the household has more lands. The index of durable goods is important, however, the same is not the case with living condition index. Similar inference is also valid regarding social group dummy. They are important in influencing the loan application equation, but not the approval equation.

Then the natural question remains: what determines the loan approval equation. Our result clearly demonstrates the role of two factors: occupational dummy (even after controlling after selection) and the purpose of the loan. Two occupational groups are definitely worse off, namely the self-employed in non-agriculture and agricultural labourer. ${ }^{11}$ Our results also show that the probability of receiving a loan increases if the purpose of the loan is for farm business compared to any other purposes.

\section{Village Characteristics}

The coefficient of presence of cooperative credit society dummy is negative and significant in the case of loan application to banks. This indicates that CCS acts as a substitute source of credit. The same is true in case of regression equation for credit cooperative society. ${ }^{12}$ The self-help group dummy is positive and significant indicating that the presence of the institutions in a village increases the chance of households applying for a loan from Banks. The coefficient of infrastructure index is positive and significant.

\footnotetext{
${ }^{11}$ See the marginal effect.

${ }^{12}$ Banks act like a substitute.
} 


\section{The Multinomial Logit Model}

The result of the multinomial logit model is presented in Table 3. As before, we report the findings in terms of household characteristics and village level variables.

\section{$\underline{\text { Household Characteristics }}$}

The results indicate that the odds are in favour of households with an account in a financial institution. An increase in the size of the family has a favourable impact on loan application to Banks, CCS, Banks-CCS, and CCS-SHG. There is a negative and significant impact on loan application to Banks, CCS, and Banks-CCS when the household head is a woman and the older the household head the lower are the chances of applying for a loan from Banks, and SHG. The odds favour those households who have subscribed to newspaper in applying for a loan to BanksCCS and CCS-SHG in contrast to those households who do not subscribe to newspaper.

The odds also favour households who possess livestock when compared to those who do not own livestock in applying for a loan to Banks, CCS, SHG, Banks-CCS, and SHG-Banks. The relative ratio of land holding dummies is positive and significant for loan application to Banks, CCS, Bank-CCS, and All FI's. The size of the coefficients indicates that households having larger land holding have a greater chance of applying for a loan in comparison to those who do not own land.

The odds favour those households who have a higher durable good index in applying for a loan from Banks, SHG, Banks-CCS, and All FI's. The relative risk ratio of the household index is negative and insignificant for all the choices except for SHG wherein it is significant. The result indicates that households with a higher household index are richer and are hence not part of SHG's. It also indicates that the lower income households participate in the self-help groups, as they would not have any other means of obtaining a loan. 
The odds favour those household self employed in non-agriculture in applying for a loan from Banks, CCS-SHG and All Financial Institutions in comparison to the 'other' households. The households who derive their main income from agricultural labour have a relative risk ratio in favour of applying to Banks, SHG, CCS-SHG, and All FI's. The odds of those households whose occupation is 'other labour' have a higher probability of applying to Banks, and CCSSHG. The odds are in favour of those households self-employed in agriculture in applying for a loan to Banks, CCS, and CCS-SHG. The social group dummies signify that the odds are against the scheduled tribe households in seeking a loan from CCS, CCS-SHG, and SHG-Banks. The odds favour the scheduled caste and OBC households in applying for a loan from banks.

\section{$\underline{\text { Village-Level Variables }}$}

The odds of a household applying for a loan from CCS decreases with the presence of commercial banks in the village whereas, presence of CCS in the village improves the chances of the household applying for a loan from CCS in comparison to the case when these institutions were outside the village. The presence of a SHG in a village improves the probability of a household in the village to apply for a loan from Banks. The presence of SHG improves the chances of the household in applying to SHG, Banks-CCS, and CCS-SHG. The presence of CCS in the village reduces the odds of the household applying to all the financial institutions. An increase in the infrastructure index has a positive impact of loan application to Banks-CCS. The education index does not have an impact on loan application.

\section{Conclusion}

This paper examines the prevalent situation of the formal financial institutions in rural India using the data from the Consumer Expenditure and Common Property Resources, National Sample Survey $54^{\text {th }}$ Round (January-June, 1998). Our results reveal that the rural households are considerably credit constrained. The households who do not have an account in a financial 
institution have a lower chance of obtaining the loan. Households who are credit constrained have relatively lower land holding and they do not possess livestock. The other factors that go against these households are the family size, caste and the age of the household head. Those households who borrow for non-farm purpose exhibit a lower chance of obtaining credit compared to those households who borrow for farm business. This could be indicative of the fact that, emphasis has been given to the priority sector when the issue of lending arises. The presence of a financial institution in the village improves the probability of households seeking a loan and improves the chances of the loan being granted. The infrastructure index reveals that the villages that have a higher index would represent better infrastructure facility and hence, improve the chances of the household applying and receiving the loan. In sum, we conclude that the lack of adequacy and access to credit in the rural credit markets still exists in India. 


\section{References}

Besley, T. (1994). How do market failures justify interventions in rural credit markets? The World Bank Research Observer, 9(1): 27-47.

Bhende, M.J. (1986). Credit Markets in rural south India. Economic and Political Weekly, Vol. XXI, Nos. 38 and 39, September 20-27, A:119-A:124.

Diagne, A. (1999). Determinants of household access to and participation in formal and informal credit markets in Malawi. IFPRI FCND Discussion Paper No.67.

Duong, P. B. and Y. Izumida (2002). Rural development finance in Vietnam: a microeconometric analysis of household surveys. World Development, 30(2): 319-335.

Khandker, S. R. and R. R. Faruque. The impact of farm credit in Pakistan. Agricultural Economics, 28(3): 197-213.

Filmer, D. and L. Pritchett (2001). Estimating wealth effects without expenditure data-or tears: an application to educational enrolments in states of India. Demography, 38(1): 115-132.

Heckman, J. (1979). Sample selection bias as a specification error. Econometrica, 47(1): 153161.

Kochar, A. (1997a). An empirical investigation of rationing constraints in rural credit markets in India. Journal of Development Economics, 53(2): 339-371.

Kochar, A. (1997b). Does lack of access to formal credit constrain agricultural production? evidence from the land tenancy market in rural India. American Journal of Agricultural Economics, 79 (3): 754-763.

Pal, S. (2002). Household sectoral choice and effective demand for credit in India. Applied Economics, 34(14): 1743-1755.

Stiglitz, J. E., and A. Weiss (1981). Credit rationing in markets with imperfect information. American Economic Review, 71(3): 393-410.

Swain, R. B. (2002). Credit rationing in rural India. Journal of Economic Development, 27(2): 120.

Zeller, M. (1994). Determinants of credit-rationing: a study of informal Lenders and formal credit groups in Madagascar. World Development, 22(12): 1895-1907. 
Table 1 Results for loan in case of Commercial banks

\begin{tabular}{|c|c|c|c|}
\hline Variables & $\begin{array}{c}\text { Loan Approved by } \\
\text { Banks } \\
\text { Second Equation }\end{array}$ & $\begin{array}{c}\text { Loan Application } \\
\text { to Banks } \\
\text { First Equation }\end{array}$ & $\begin{array}{c}\text { Marginal } \\
\text { Effects }\end{array}$ \\
\hline \multicolumn{4}{|l|}{$\underline{\text { Household Level variables }}$} \\
\hline Household has an account (if yes $=1$ ) & & $\begin{array}{c}0.639 \\
(0.000)^{* * *}\end{array}$ & 0.166 \\
\hline Family Size & $\begin{array}{c}-0.027 \\
(0.002)^{* * *}\end{array}$ & $\begin{array}{c}0.025 \\
(0.000)^{* * *}\end{array}$ & -0.006 \\
\hline Sex of the head of the Household (if female $=1$ ) & $\begin{array}{c}0.225 \\
(0.015)^{* *}\end{array}$ & $\begin{array}{c}-0.238 \\
(0.000)^{* * *}\end{array}$ & 0.035 \\
\hline Age of the head of the Household & $\begin{array}{c}-0.002 \\
(-0.294)\end{array}$ & $\begin{array}{c}-0.001 \\
(0.073)^{*}\end{array}$ & -0.001 \\
\hline Household subscribes to a newspaper (if yes $=1$ ) & $\begin{array}{c}0.061 \\
(-0.509)\end{array}$ & $\begin{array}{c}0.088 \\
(0.031)^{* *}\end{array}$ & 0.051 \\
\hline \multicolumn{4}{|l|}{ Economic Condition } \\
\hline Household posses livestock (if yes $=1$ ) & $\begin{array}{c}0.016 \\
(-0.735)\end{array}$ & $\begin{array}{c}0.185 \\
(0.000)^{* * *}\end{array}$ & 0.060 \\
\hline \multicolumn{4}{|l|}{ Land Possession Dummy } \\
\hline If less than 2.5 acres & $\begin{array}{c}-0.043 \\
(-0.543)\end{array}$ & $\begin{array}{c}0.104 \\
(0.004)^{* * * *}\end{array}$ & 0.010 \\
\hline If more than 2.5 acres less than 5 acres & $\begin{array}{c}-0.031 \\
(-0.737)\end{array}$ & $\begin{array}{c}0.196 \\
(0.000)^{* * * *}\end{array}$ & 0.040 \\
\hline If more than 5 acres & $\begin{array}{c}0.047 \\
(0.639)\end{array}$ & $\begin{array}{c}0.254 \\
(0.000)^{* * * *}\end{array}$ & 0.087 \\
\hline Index of Durable Goods & $\begin{array}{l}-0.007 \\
(0.687)\end{array}$ & $\begin{array}{c}0.042 \\
(0.000)^{* * *}\end{array}$ & 0.009 \\
\hline Index of Living Condition & $\begin{array}{c}0.002 \\
(0.914)\end{array}$ & $\begin{array}{l}-0.005 \\
(0.631)\end{array}$ & 0.000 \\
\hline \multicolumn{4}{|l|}{ Occupational Dummy } \\
\hline Self employment in non-agriculture & $\begin{array}{c}-0.334 \\
(0.000)^{* * *}\end{array}$ & $\begin{array}{c}0.505 \\
(0.000)^{* * *}\end{array}$ & -0.014 \\
\hline Agricultural labour & $\begin{array}{c}-0.198 \\
(0.016)^{* *}\end{array}$ & $\begin{array}{c}0.247 \\
(0.000)^{* * *}\end{array}$ & -0.022 \\
\hline Other labour & $\begin{array}{l}-0.104 \\
(0.307)\end{array}$ & $\begin{array}{c}0.226 \\
(0.000)^{* * *}\end{array}$ & 0.015 \\
\hline Self employment in agriculture & $\begin{array}{c}-0.181 \\
(0.029)^{* *}\end{array}$ & $\begin{array}{c}0.326 \\
(0.000)^{* * *}\end{array}$ & 0.008 \\
\hline \multicolumn{4}{|l|}{ Social Group Dummy } \\
\hline Scheduled Tribe & $\begin{array}{c}0.031 \\
(0.769)\end{array}$ & $\begin{array}{c}0.028 \\
(0.572)\end{array}$ & 0.022 \\
\hline Scheduled Caste & $\begin{array}{l}-0.059 \\
(0.393)\end{array}$ & $\begin{array}{c}0.170 \\
(0.000)^{* * *}\end{array}$ & 0.021 \\
\hline Other Backward Caste & $\begin{array}{c}0.019 \\
(0.732)\end{array}$ & $\begin{array}{c}0.055 \\
(0.051)^{*}\end{array}$ & 0.025 \\
\hline
\end{tabular}


Table 1 continued

\section{Purpose of Loan Dummy}

Farm business loan

0.163

0.075

$(0.012)^{* *}$

$-0.142$

$-0.065$

Non-farm business loan

$(0.031)^{* *}$

Financial Investment by Household

$-0.138$

$-0.064$

$(0.410)$

Debt repayment

$-0.318$

$(0.068)^{*}$

Medical/Educational

$-0.147$

0.054

$(0.814)$

0.025

$\underline{\text { Village Level variables }}$

Presence of Commercial Bank inside the Village

0.002

(0.978)

0.054

(0.319)

0.107

$-0.099$

$(0.189)$

$(0.040)^{* * *}$

0.08

$-0.008$

Village

$(0.384)$

0.044

$(0.520)$

$-0.018$

$(0.525)$

$-0.032$

$(0.202)$

$(0.884)$

0.082

$(0.040)^{* * *}$

$-0.008$

$(0.601)$

0.017

$(0.210)$

0.016

0.021

0.034

0.003

$-0.011$

Infrastructural Facility Index

$(0.202)$

$\operatorname{Pr}$ (loan approval=1/ loan application=1)

$-14058.18$

Log pseudo-likelihood

Note: Wald test of independent equations: $\chi^{2}(1)=57.14$. State Dummies included. Robust $p$-values adjusted for clustering are in parentheses. $*$ denotes significant at $10 \%$; ** significant at $5 \%$; *** significant at $1 \%$. The conditional marginal effect is reported in the last column implying given the probability of applying for a loan $=1$ conditional on the probability of loan being granted $=1$. 
Table 2 Results for loan in case of Credit Cooperative Society (CCS)

\begin{tabular}{|c|c|c|c|}
\hline Variables & $\begin{array}{c}\text { Loan Approved by } \\
\text { CCS } \\
\text { Second Equation }\end{array}$ & $\begin{array}{c}\text { Loan Application } \\
\text { to CCS } \\
\text { First Equation } \\
\end{array}$ & $\begin{array}{l}\text { Marginal } \\
\text { Effects }\end{array}$ \\
\hline \multicolumn{4}{|l|}{$\underline{\text { Household Level variables }}$} \\
\hline Household has an account (if yes $=1$ ) & & $\begin{array}{c}0.732 \\
(0.000)^{* * *}\end{array}$ & 0.119 \\
\hline Family Size & $\begin{array}{c}0.011 \\
(0.335)\end{array}$ & $\begin{array}{c}0.011 \\
(0.009)^{* * *}\end{array}$ & 0.006 \\
\hline Sex of the head of the Household (if female $=1$ ) & $\begin{array}{c}0.054 \\
(0.702)\end{array}$ & $\begin{array}{c}-0.234 \\
(0.000)^{* * *}\end{array}$ & -0.020 \\
\hline Age of the head of the Household & $\begin{array}{c}0.004 \\
(0.073)^{*}\end{array}$ & $\begin{array}{c}0.001 \\
(0.425)\end{array}$ & 0.002 \\
\hline Household subscribes to a newspaper (if yes $=1$ ) & $\begin{array}{l}-0.074 \\
(0.557)\end{array}$ & $\begin{array}{c}0.006 \\
(0.889)\end{array}$ & -0.028 \\
\hline \multicolumn{4}{|l|}{ Economic Condition } \\
\hline Household posses livestock (if yes = 1) & $\begin{array}{c}0.081 \\
(0.318)\end{array}$ & $\begin{array}{c}0.188 \\
(0.000)^{* * *}\end{array}$ & 0.064 \\
\hline \multicolumn{4}{|l|}{ Land Possession Dummy } \\
\hline If less than 2.5 acres & $\begin{array}{l}-0.105 \\
(0.377)\end{array}$ & $\begin{array}{c}0.341 \\
(0.000)^{* * * *}\end{array}$ & 0.019 \\
\hline If more than 2.5 acres less than 5 acres & $\begin{array}{l}-0.148 \\
(0.319)\end{array}$ & $\begin{array}{c}0.481 \\
(0.000)^{* * *}\end{array}$ & 0.025 \\
\hline If more than 5 acres & $\begin{array}{c}0.017 \\
(0.918)\end{array}$ & $\begin{array}{c}0.644 \\
(0.000)^{* * *}\end{array}$ & 0.105 \\
\hline Index of Durable Goods & $\begin{array}{c}0.039 \\
(0.159)\end{array}$ & $\begin{array}{c}0.024 \\
(0.021)^{* *}\end{array}$ & 0.019 \\
\hline Index of Living Condition & $\begin{array}{c}0.009 \\
(0.792)\end{array}$ & $\begin{array}{l}-0.015 \\
(0.259)\end{array}$ & 0.001 \\
\hline \multicolumn{4}{|l|}{ Occupational Dummy } \\
\hline Self employment in non-agriculture & $\begin{array}{l}-0.235 \\
(0.105)\end{array}$ & $\begin{array}{c}0.009 \\
(0.849)\end{array}$ & -0.093 \\
\hline Agricultural labour & $\begin{array}{l}-0.212 \\
(0.110)\end{array}$ & $\begin{array}{c}0.047 \\
(0.270)\end{array}$ & -0.074 \\
\hline Other labour & $\begin{array}{l}-0.123 \\
(0.440)\end{array}$ & $\begin{array}{c}0.019 \\
(0.718)\end{array}$ & -0.045 \\
\hline Self employment in agriculture & $\begin{array}{l}-0.161 \\
(0.235)\end{array}$ & $\begin{array}{c}0.246 \\
(0.000) * * *\end{array}$ & -0.019 \\
\hline \multicolumn{4}{|l|}{ Social Group Dummy } \\
\hline Scheduled Tribe & $\begin{array}{c}0.019 \\
(0.898)\end{array}$ & $\begin{array}{c}-0.165 \\
(0.010)^{* *}\end{array}$ & -0.022 \\
\hline Scheduled Caste & $\begin{array}{l}-0.111 \\
(0.276)\end{array}$ & $\begin{array}{c}0.023 \\
(0.536)\end{array}$ & -0.039 \\
\hline Other Backward Caste & $\begin{array}{l}-0.028 \\
(0.762)\end{array}$ & $\begin{array}{c}0.035 \\
(0.324)\end{array}$ & -0.005 \\
\hline
\end{tabular}


Table 2 continued

\section{Purpose of Loan Dummy}

Farm business loan

0.044

0.017

$(0.672)$

Non-farm business loan

$-0.504$

$-0.193$

$(0.000)^{* * * *}$

$-0.399$

$-0.153$

Financial Investment by Household

$(0.087)^{*}$

Debt repayment

$-0.131$

$-0.050$

Medical/Educational

$(0.593)$

0.054

(0.662)

\section{$\underline{\text { Village Level variables }}$}

Presence of Commercial Bank inside the Village

0.046

$(0.722)$

0.012

$(0.912)$

$-0.120$

$-0.153$

$-0.009$

Presence of Cooperative Bank inside the Village

$(0.007)^{* * *}$

0.183

0.035

Presence of Regional Rural Bank inside the

$(0.334)$

$(0.000)^{* * *}$

Village

$-0.071$

Presence of Self-Help Group inside the Village

0.065

$(0.530)$

$(0.283)$

$-0.060$

$-0.069$

0.041

$(0.378)$

Educational Facility Index

$(0.083)^{*}$

$-0.005$

$(0.779)$

0.023

0.030

$(0.556)$

$(0.084)^{*}$

0.031

$-0.027$

0.014

$\operatorname{Pr}$ (loan approval=1| loan application=1)

Log pseudo-likelihood

$-10019.91$

0.722

Note: Wald test of independent equations: $\chi^{2}(1)=13.58$. State Dummies are included. Robust $p$-values adjusted for clustering are in parentheses. * denotes significant at $10 \%$; ** significant at $5 \%$; *** significant at $1 \%$. The conditional marginal effect is reported in the last column implying given the probability of applying for a loan $=1$ conditional on the probability of loan being granted $=1$. 
Table 3 Multinomial Logit Model including village facilities

\begin{tabular}{|c|c|c|c|c|c|c|c|}
\hline Variables & $\begin{array}{l}\text { Bank } \\
\text { RRR }\end{array}$ & $\begin{array}{l}\text { CCS } \\
\text { RRR }\end{array}$ & $\begin{array}{l}\text { SHG } \\
\text { RRR }\end{array}$ & $\begin{array}{l}\text { Bank-CCS } \\
\text { RRR }\end{array}$ & $\begin{array}{l}\text { CCS-SHG } \\
\text { RRR }\end{array}$ & $\begin{array}{l}\text { SHG-Bank } \\
\text { RRR }\end{array}$ & $\begin{array}{l}\text { All } \\
\text { RRR }\end{array}$ \\
\hline \multicolumn{8}{|l|}{ Household Level } \\
\hline \multicolumn{8}{|l|}{$\overline{\text { Variables }}$} \\
\hline $\begin{array}{l}\text { Household has an account } \\
\text { (if yes = 1) }\end{array}$ & 4.197 & 5.555 & 1.851 & 5.797 & 2.056 & 4.662 & 1.795 \\
\hline & $(0.000)^{* * * *}$ & $(0.000) * * *$ & $(0.002)^{* * *}$ & $(0.000)^{* * *}$ & $(0.066)^{*}$ & $(0.000)^{* * *}$ & $(0.020)^{* *}$ \\
\hline Family Size & $\begin{array}{l}1.052 \\
(0.000) * * *\end{array}$ & $\begin{array}{l}1.027 \\
(0.005)^{* * *}\end{array}$ & $\begin{array}{l}1.014 \\
(0.567)\end{array}$ & $\begin{array}{l}1.040 \\
(0.066)^{*}\end{array}$ & $\begin{array}{l}1.089 \\
(0.005)^{* * *}\end{array}$ & $\begin{array}{l}1.022 \\
(0.626)\end{array}$ & $\begin{array}{l}0.977 \\
(0.397)\end{array}$ \\
\hline $\begin{array}{l}\text { Sex of the head of the } \\
\text { Household (if female }=1 \text { ) }\end{array}$ & $(0.000) * * *$ & $(0.000) * * *$ & 0.834 & $(0.035) * *$ & 0.685 & 1.298 & 1.050 \\
\hline $\begin{array}{l}\text { Age of the head of the } \\
\text { Household }\end{array}$ & 0.996 & 1.000 & 0.989 & 0.997 & 1.005 & 1.002 & 1.006 \\
\hline $\begin{array}{l}\text { Household subscribes to a } \\
\text { newspaper (if yes }=1 \text { ) }\end{array}$ & $\begin{array}{l}(0.012)^{* *} \\
1.066\end{array}$ & $\begin{array}{l}(0.963) \\
0.950\end{array}$ & $\begin{array}{l}(0.033)^{* *} \\
1.154\end{array}$ & $\begin{array}{l}(0.618) \\
1.749\end{array}$ & $\begin{array}{l}(0.671) \\
3.759\end{array}$ & $\begin{array}{l}(0.836) \\
1.938\end{array}$ & $\begin{array}{l}(0.275) \\
1.653\end{array}$ \\
\hline Economic Condition & $(0.470)$ & $(0.610)$ & $(0.655)$ & $(0.011)^{* *}$ & $(0.028)^{* *}$ & $(0.165)$ & $(0.137)$ \\
\hline $\begin{array}{l}\text { Household posses livestock } \\
(\text { if yes = 1) }\end{array}$ & 1.530 & 1.538 & 1.380 & 1.891 & 1.503 & 3.783 & 0.977 \\
\hline & $(0.000)^{* * *}$ & $(0.000)^{* * *}$ & $(0.047)^{* *}$ & $(0.001)^{* * *}$ & $(0.301)$ & $(0.000)^{* * *}$ & $(0.933)$ \\
\hline Land Possession Dummy & & & & & & & \\
\hline If less than 2.5 acres & $\begin{array}{l}1.270 \\
(0.003)^{* * *}\end{array}$ & $\begin{array}{l}2.134 \\
(0.000) * * *\end{array}$ & $\begin{array}{l}1.365 \\
(0.171)\end{array}$ & $\begin{array}{l}1.281 \\
(0.454)\end{array}$ & $\begin{array}{l}1.034 \\
(0.943)\end{array}$ & $\begin{array}{l}2.035 \\
(0.135)\end{array}$ & $\begin{array}{l}1.942 \\
(0.025)^{* *}\end{array}$ \\
\hline $\begin{array}{l}\text { If more than } 2.5 \text { acres } \\
\text { less than } 5 \text { acres }\end{array}$ & 1.551 & 2.897 & 1.436 & 2.127 & 0.571 & 1.625 & 2.488 \\
\hline If more than 5 acres & $\begin{array}{l}(0.000)^{* * *} \\
1.745 \\
(0.000)^{* * *}\end{array}$ & $\begin{array}{l}(0.000)^{* * *} \\
3.783 \\
(0.000) * * *\end{array}$ & $\begin{array}{l}(0.290) \\
1.796 \\
(0.106)\end{array}$ & $\begin{array}{l}(0.022)^{* *} \\
4.078 \\
(0.000)^{* * *}\end{array}$ & $\begin{array}{l}(0.441) \\
1.301 \\
(0.678)\end{array}$ & $\begin{array}{l}(0.440) \\
1.353 \\
(0.629)\end{array}$ & $\begin{array}{l}(0.004)^{* * *} \\
3.066 \\
(0.002)^{* * *}\end{array}$ \\
\hline Index of Durable Goods & $\begin{array}{l}1.067 \\
(0.001)^{* * *}\end{array}$ & $\begin{array}{l}1.022 \\
(0.331)\end{array}$ & $\begin{array}{l}1.112 \\
(0.059)^{*}\end{array}$ & $\begin{array}{l}1.131 \\
(0.006)^{* * *}\end{array}$ & $\begin{array}{l}1.091 \\
(0.268)\end{array}$ & $\begin{array}{l}1.097 \\
(0.309)\end{array}$ & $\begin{array}{l}1.331 \\
(0.003)^{* * *}\end{array}$ \\
\hline Index of Living Condition & $\begin{array}{l}0.987 \\
(0.557)\end{array}$ & $\begin{array}{l}0.967 \\
(0.254)\end{array}$ & $\begin{array}{l}0.874 \\
(0.054)^{*}\end{array}$ & $\begin{array}{l}0.963 \\
(0.574)\end{array}$ & $\begin{array}{l}0.965 \\
(0.813)\end{array}$ & $\begin{array}{l}1.012 \\
(0.935)\end{array}$ & $\begin{array}{l}1.115 \\
(0.389)\end{array}$ \\
\hline Occupational Dummy & & & & & & & \\
\hline $\begin{array}{l}\text { Self employment in non- } \\
\text { agriculture }\end{array}$ & 2.906 & 1.022 & 1.251 & 1.253 & 19.928 & 1.129 & 1.876 \\
\hline & $(0.000)^{* * *}$ & $(0.845)$ & $(0.327)$ & $(0.402)$ & $(0.005)^{* * *}$ & $(0.812)$ & $(0.013)^{* *}$ \\
\hline Agricultural Labour & $\begin{array}{l}1.757 \\
(0.000) * * *\end{array}$ & $\begin{array}{l}1.151 \\
(0.172)\end{array}$ & $\begin{array}{l}1.573 \\
(0.061)^{*}\end{array}$ & $\begin{array}{l}1.157 \\
(0.569)\end{array}$ & $\begin{array}{l}7.539 \\
(0.063)^{*}\end{array}$ & $\begin{array}{l}0.574 \\
(0.240)\end{array}$ & $\begin{array}{l}1.998 \\
(0.011)^{* *}\end{array}$ \\
\hline Other Labour & $\begin{array}{l}1.671 \\
(0.000) * * *\end{array}$ & $\begin{array}{l}1.087 \\
(0.476)\end{array}$ & $\begin{array}{l}1.275 \\
(0.422)\end{array}$ & $\begin{array}{l}0.978 \\
(0.953)\end{array}$ & $\begin{array}{l}6.827 \\
(0.097) *\end{array}$ & $\begin{array}{l}1.630 \\
(0.447)\end{array}$ & $\begin{array}{l}1.510 \\
(0.215)\end{array}$ \\
\hline $\begin{array}{l}\text { Self employment in } \\
\text { agriculture }\end{array}$ & $\begin{array}{l}2.137 \\
(0.000)^{* * * *}\end{array}$ & $\begin{array}{l}1.920 \\
(0.000)^{* * *}\end{array}$ & $\begin{array}{l}1.089 \\
(0.728)\end{array}$ & $\begin{array}{l}1.344 \\
(0.161)\end{array}$ & $\begin{array}{l}13.174 \\
(0.015)^{* *}\end{array}$ & $\begin{array}{l}0.935 \\
(0.864)\end{array}$ & $\begin{array}{l}0.999 \\
(0.998)\end{array}$ \\
\hline Social Group Dummy & & & & & & & \\
\hline Scheduled Tribe & $\begin{array}{l}1.078 \\
(0.510)\end{array}$ & $\begin{array}{l}0.706 \\
(0.028) * *\end{array}$ & $\begin{array}{l}0.568 \\
(0.167)\end{array}$ & $\begin{array}{l}0.962 \\
(0.911)\end{array}$ & $\begin{array}{l}0.000 \\
(0.000) * * *\end{array}$ & $\begin{array}{l}0.000 \\
(0.000) * * *\end{array}$ & $\begin{array}{l}1.078 \\
(0.808)\end{array}$ \\
\hline Scheduled Caste & $\begin{array}{l}1.441 \\
(0.000) * * *\end{array}$ & $\begin{array}{l}1.066 \\
(0.477)\end{array}$ & $\begin{array}{l}0.948 \\
(0.784)\end{array}$ & $\begin{array}{l}0.811 \\
(0.324)\end{array}$ & $\begin{array}{l}1.139 \\
(0.766)\end{array}$ & $\begin{array}{l}1.227 \\
(0.597)\end{array}$ & $\begin{array}{l}1.363 \\
(0.222)\end{array}$ \\
\hline Other Backward caste & $\begin{array}{l}1.125 \\
(0.056)^{*}\end{array}$ & $\begin{array}{l}1.114 \\
(0.193)\end{array}$ & $\begin{array}{l}0.756 \\
(0.121)\end{array}$ & $\begin{array}{l}0.878 \\
(0.451)\end{array}$ & $\begin{array}{l}0.635 \\
(0.296)\end{array}$ & $\begin{array}{l}1.131 \\
(0.747)\end{array}$ & $\begin{array}{l}1.004 \\
(0.986)\end{array}$ \\
\hline
\end{tabular}


Table 3 continued

\begin{tabular}{|c|c|c|c|c|c|c|c|}
\hline & Bank & CCS & SHG & Bank-CCS & CCS-SHG & SHG-Bank & All \\
\hline Village Level Variables & RRR & RRR & RRR & RRR & RRR & RRR & RRR \\
\hline \multirow{2}{*}{$\begin{array}{l}\text { Presence of Commercial } \\
\text { Bank inside the Village }\end{array}$} & 1.174 & 0.744 & 1.187 & 0.718 & 0.549 & 0.914 & 0.862 \\
\hline & $(0.130)$ & $(0.013)^{* *}$ & $(0.525)$ & $(0.220)$ & $(0.196)$ & $(0.825)$ & $(0.649)$ \\
\hline \multirow{2}{*}{$\begin{array}{l}\text { Presence of Cooperative } \\
\text { Bank inside the Village }\end{array}$} & 0.859 & 1.540 & 1.113 & 1.080 & 0.654 & 1.173 & 0.548 \\
\hline & $(0.114)$ & $(0.000)^{* * *}$ & $(0.694)$ & $(0.745)$ & $(0.323)$ & $(0.622)$ & $(0.089)^{*}$ \\
\hline \multirow{2}{*}{$\begin{array}{l}\text { Presence of Regional Rural } \\
\text { Banks inside the Village }\end{array}$} & 0.948 & 0.820 & 1.122 & 0.762 & 0.779 & 0.722 & 1.613 \\
\hline & $(0.602)$ & $(0.134)$ & $(0.716)$ & $(0.337)$ & $(0.637)$ & $(0.418)$ & $(0.149)$ \\
\hline \multirow{3}{*}{$\begin{array}{l}\text { Presence of Self-Help } \\
\text { Group inside the Village }\end{array}$} & 1.186 & 1.084 & 2.857 & 1.479 & 2.189 & 1.309 & 1.489 \\
\hline & & & & & & & \\
\hline & $(0.030)^{* * *}$ & $(0.420)$ & $(0.000)^{* * *}$ & $(0.054)^{*}$ & $(0.025)^{* *}$ & $(0.359)$ & $(0.227)$ \\
\hline \multirow{2}{*}{ Educational Facility Index } & 0.969 & 0.988 & 1.064 & 0.940 & 1.165 & 1.312 & 0.981 \\
\hline & $(0.315)$ & $(0.767)$ & $(0.394)$ & $(0.475)$ & $(0.128)$ & $(0.105)$ & $(0.861)$ \\
\hline \multirow{2}{*}{$\begin{array}{l}\text { Infrastructural Facility } \\
\text { Index }\end{array}$} & 1.035 & 1.052 & 0.994 & 1.132 & 1.036 & 0.924 & 0.937 \\
\hline & $(0.204)$ & $(0.165)$ & $(0.956)$ & $(0.088)^{*}$ & $(0.811)$ & $(0.606)$ & $(0.612)$ \\
\hline State Dummy Included & Yes & & & & & & \\
\hline Observations & 58599 & & & & & & \\
\hline Wald $\chi^{2}$ & 916853.20 & & & & & & \\
\hline Prob $>\chi^{2}$ & 0.0000 & & & & & & \\
\hline Pseudo $\mathrm{R}^{2}$ & 0.7989 & & & & & & \\
\hline Log pseudo-likelihood & -24500.335 & & & & & & \\
\hline
\end{tabular}

Note: RRR implies the relative risk-ratio. Robust $p$-values adjusted for clustering are in parentheses. * significant at $10 \%$; ** significant at $5 \%$; *** significant at $1 \%$. 